Linguistics and

LHS (PRINT) ISSN 1742-2906

the Human

LHS (ONLINE) ISSN 1743-1662

\title{
Sciences
}

Article

\section{The interpersonal origins of language: social and linguistic implications of an archaeological approach to language evolution}

\author{
Ben Marwick
}

\begin{abstract}
The development of the interpersonal functions of language is a key step in language ontogeny. Archaeological evidence of hominids moving raw materials across the landscape suggest that changes in the interpersonal communication abilities of hominids represent major events in human language evolution. The earliest hominids moved raw materials short distances, suggesting home-range sizes, social complexity and interpersonal abilities similar to those of primates. A transition from primate communication to a protolanguage is indicated by a large increase in raw-material transfer distances at about 1.2 million years ago. The increase in transfer distances results from the ability to pool social and environmental information using a protolanguage. The transition to human language is suggested by the emergence of long-distance exchange networks during the African Middle Stone Age. The operation of exchange networks requires the full panoply of human interpersonal communication abilities, such as the use of symbols in social contexts, expression of displacement, the expression of multiple degrees of intentionality and recursiveness. The results of computer simulations show that this transition from protolanguage to full language may have resulted from language adapting itself rather than any specific biological or cultural mutation.
\end{abstract}

KEYWORDS: NONE SUPPLIED

\section{Affiliation}

Ben Marwick, [full address needed] Research School of Pacific and Asian Studies, Australian National University email: please supply 


\section{Introduction}

The function of language according to Halliday (1994) is threefold, to represent the world around us (ideational), to interact with other speakers (interpersonal) and to organise ideational and interpersonal meanings into a message (textual). Many archaeologists writing about language evolution concentrate on identifying ideational functions as the first evidence for symbolic linguistic abilities in hominids (e.g. Mithen, 1996; Noble and Davidson, 1996). This generally results in a focus on when predetermined forms are intentionally imposed on stone and bone artefacts (Davidson, 2002) and when Palaeolithic paintings and engravings became more than simple iconic representations (Henshilwood et al., 2002). There is very little literature by archaeologists on the evolution of language through the identification of interpersonal systems, although it is a popular approach with writers in other disciplines (e.g. Dunbar, 1996; Wray, 2000). Of course the textual function of language is of limited relevance to archaeologists working on the evolution of language because the first evidence of writing only dates to about $3500 \mathrm{BC}$ and the earliest recorded speech dates to the mid-nineteenth century - some millennia after its origin.

This silence of archaeologists on the importance of the interpersonal domain in language evolution is problematic for two reasons. Firstly, the work of Halliday (1993) and Painter (2004) on language development during childhood shows that the interpersonal function of language is the engine that drives first linguistic development. Secondly, of all the disciplines involved in language evolution research, archaeologists have one of the strongest claims to knowledge of such a major change in human evolutionary development because they deal with the residues of the changing behaviours. This means that archaeologists can make claims about how social and economic behaviours changed as a result of the emergence of language. These claims can be compared to the more speculative assertions of palaeoanthropologists about the language potential indicated by certain lumps and ridges in hominid fossil bones (e.g. Holloway, 1983). The archaeologist is not limited to the often equivocal expressions of non-human primates or the guided language development of children but has direct access to the material results of the process of language evolution in hominids.

The aim of this paper is to present an interpretation of the archaeological record that is mainly focused on the interpersonal aspects of language evolution. I explore the interpersonal implications of a previously published archaeological narrative of language evolution (Marwick, 2003). This narrative interpreted changes in distances of raw-material transfer as evidence for evolutionary changes in interpersonal communication systems. In this context, an 'occurrence' of a raw-material transfer is defined by one or more 
associated artefacts made from a raw material that can be sourced to a specific location. For example, one occurrence can be a single chert artefact that is sourced to an outcrop $5 \mathrm{~km}$ away, or several hundred pieces of obsidian in the same stratigraphic context that can be sourced to an outcrop $40 \mathrm{~km}$ away. I use a chronological framework to discuss and compare three major periods of language evolution suggested by the archaeological record and explain what this evidence suggests about changes in the hominid interpersonal domain.

\section{Early Homo and the primate analogy}

The first stage of the model argues that the makers of the first stone artefacts were non-linguistic and used only a system of communication that is directly analogous to primate communication. This is suggested by similar sizes of home-range radius and similar life histories.

The home-range size of early hominids can be inferred from distances of transfer for raw materials used to make stone artefacts. The first stone artefacts date to 2.5 million years ago in Ethiopia (Semaw, 2000) but it is not until 1.9 million years ago that Homo habilis appears in the East African Rift Valley (Klein, 1999) and large numbers of stone artefacts are produced. During the period 1.9-1.6 million years ago there are data on 26 instances of raw-material transfers from 12 sites or layers at Olduvai Gorge (Tanzania) and Koobi Fora (Kenya) (Feblot-Augustins, 1997: inventory 3-4). Most of these transfers were over a distance of three kilometres or less, with a small number of transfers at greater distances to a maximum of $13 \mathrm{~km}$. Over 95 per cent of artefacts are made on stone collected from a distance of $3 \mathrm{~km}$ or less (Feblot-Augustins, 1997: inventory 4). These data suggest a home-range radius of about $13 \mathrm{~km}$ for hominids at 1.9-1.6 million years ago. I do not think it is important to distinguish between the movement of the raw material in one trip or in a series of small events. The important detail here is that these hominids had the cognitive capacity to acquire raw material and maintain an awareness of its use until they were $13 \mathrm{~km}$ from the source.

Analysis of different kinds of data indicates a similar home-range size for these hominids. Steele (1996) has calculated hominid home-range sizes from regression equations involving measurements of adult body mass, brain volume, group size and home-range diameters of primate groups. Based on estimations of body mass and brain volume from fossils, Steele (1996: 249) predicts a homerange radius of $13 \mathrm{~km}$ for a group of 25 Homo habilis individuals.

The chimpanzees at Mt Assirik (Senegal) are a useful population to compare home-range sizes because they inhabit an arid environment similar to that of early Homo habilis (McGrew et al., 1981; Reed, 1997). The home-range size for the Mt Assirik chimpanzees is $278-333 \mathrm{~km}^{2}$ which gives a radius of $9.4-10.3 \mathrm{~km}$ 
(Baldwin et al., 1982). This evidence from the Mt Assirik chimpanzees suggests that the home-range radius of early Homo habilis is generally similar to the home-range radius for primates in comparable environments.

The significance of the similarity in home-range sizes between primates and early Homo habilis is that it indicates similarly limited abilities to collect, share and use information about the social and natural environment. In other words, the communication systems of primates and early Homo habilis probably had similar interpersonal and ideational functions. Further evidence for similarities in the interpersonal domain comes from reconstructions of life-history based on palaeontological sources. Data on dental microanatomy and brain size from early hominids suggest a short maturation period and a short life-span similar to those of large primates (Smith and Tompkins, 1995). The short maturation means that the language learning period for early Homo was very brief compared to modern humans, so any language skills possessed by early Homo is likely to have been hardwired generalised abilities such as the fast-mapping between objects and sounds recently demonstrated by the dog Rico (Kaminski et al., 2004). Amongst primates, maturation period, life-span and brain size are correlated with social complexity, measured as a function of group size (Dunbar, 1992; 1993; Joffe, 1997). The similarity in home-range size and life history between late Pliocene hominids and primates supports the analogy of primate social organization and communication for early hominids.

The interpersonal domain of primates has been well-documented and, although complex, is typified by dominant males who control the movement of the group based largely on their own knowledge of the landscape and their own social status (Garber, 2000: 271-2; Goodall, 1986: 207-30). A second feature of chimpanzee interaction is that interaction between strangers (that is, individuals that are not biological kin) is often a long and uncertain process that includes display, fighting and injury (Goodall, 1986: 331, 488-534; Wilson and Wrangham, 2003; Wrangham, 1987: 66-8). The significance of these details is that primates are limited in their sharing of information about resource distribution on the landscape within their kin groups (because of their dependence on dominant males) and especially limited between non-kin groups (because of the uncertainty of these encounters). This 'closed circuit' system may be explained by the inability of primates to be aware of the psychological state of other individuals. Experiments with primates (and humans) show that primates are not consistently able to conceptualise the mental states of other individuals (Taglialatela et al., 2004). This limits their ability to anticipate supply and demand of resource and social information with other individuals, which minimises information sharing during interpersonal exchanges. These features are important variables that limit the home-range size of primate groups. 
These features of the primate interpersonal domain are largely explained by their communication system. Chimpanzee communication consists entirely of sounds, postures and facial expressions that they use to influence the behaviour of other individuals. Primate sounds are generally bound to particular emotions or affective states and refer to whole events with very limited independence of emotion or arousal (Lieberman, 1994). The non-vocal aspects of chimpanzee communication such as grooming have been argued by Dunbar (2003) to be a means of exchanging social information by demonstrating alliances. Dunbar notes that grooming as a means of communication is limited because only one individual can be groomed at a time and other activities (such as walking, feeding or collecting food) are not possible. Chimpanzee communication, as observed in the wild, is without syntax (there is no structure of phrases nested within phrases, so they cannot relate multiple sets of concepts or objects to others) and displacement (so they are unable to refer beyond the here-and-now, what they do not directly experience they will never know about), although wild chimpanzees may have some symbolic elements in their communication. Chimpanzee communication can be summarised as limited in potential (they cannot express a great range of concepts) and flexibility (the system is only useful in certain contexts).

According to this primate analogy, the communication system of early Homo was one of non-syntactic expressions with limited semiotic capacity produced to alter the behaviour of individuals in the immediate context. The interpersonal domain of early Homo consisted of individuals communicating mostly between members of their kin-group with limited ability to share information about the distribution of landscape resources. That said, the analogy is slightly imperfect because although primates and early Homo have similar home-range sizes and life histories, the distances that a primate transfers raw material is actually significantly less than that of early Homo.

Observations of chimpanzees in the tropical rainforest of Taï National Park (Ivory Coast) show that of 603 transports of stone and wood hammers used for nut cracking, 83.5 per cent $(n=504)$ are over less than $50 \mathrm{~m}$ (Boesch and Boesch, 1984). Transport distances of $50-500 \mathrm{~m}$ represent 16 per cent $(\mathrm{n}=$ 96) and distances over $500 \mathrm{~m}$ represent 0.5 per cent of all observed transports (Boesch and Boesch, 1984). The Taï National Park chimpanzees live in a home-range of $27 \mathrm{~km}^{2}$, indicating a theoretical radius of $2.9 \mathrm{~km}$ (Boesch and Boesch, 1984). Assuming $500 \mathrm{~m}$ as a maximum raw material transport distance, chimpanzees moved objects a distance equal to 17 per cent of their home-range radius. On the other hand, the archaeological and anatomical evidence discussed above suggests that early hominids moved objects 100 per cent of their home-range radius. 
The significance of this difference is that the early hominids demonstrated a capacity to plan to use an object over a longer distance (and therefore time) than primates. This suggests that early Homo had more developed cognitive facilities relating to planning and activity scheduling than modern primates. These cognitive abilities are probably the most significant non-anatomical divergence between the common ancestor of modern primates and early Homo. The similarity in the data on home-range size and life history suggest that the planning abilities of early Homo were largely unrelated to communication and this difference in cognitive abilities had little influence in the interpersonal domain.

\section{Social and linguistic abilities of non-modern Homo}

The second stage of the model argues for the emergence of a communication system that has no analogy, occupying the space between animal communication and full human language. Dunbar (2003) argues that the gradual increase in brain size within the Homo genus occurring between early Homo and modern Homo sapiens represents group sizes, communication systems and levels of intentionality that are intermediate between primates and modern humans. Dunbar's interpolations suggest Homo erectus ${ }^{1}$ used a communication system that overcame some of the limitations of primate social interactions. This system is often referred to as a protolanguage and sometimes compared to pidgin languages and the utterances of trained primates and young children (cf. Bickerton, 1981; Halliday, 1975; 2004; Painter, this volume).

The archaeological evidence of raw-material transfers by Homo erectus sheds some light on the potential and flexibility of this protolanguage. For the period 1.6-1.2 million years ago there are data on 45 raw-material transfers from 14 East African sites or layers (Feblot-Augustins, 1997: inventories 6 and 7). Similar to the Homo habilis pattern, the majority of raw material acquired by Homo erectus was from sources near the point of discard: 98 per cent of stone for artefacts was procured from a distance of $4 \mathrm{~km}$ or less (Feblot-Augustins, 1997: inventories 6 and 7). The maximum distance of raw-material transfer is 15 $\mathrm{km}$, indicating similar strategies of raw material procurement and landscape use to those of the period 1.9-1.6 million years ago, where the maximum distance was $13 \mathrm{~km}$. A striking change occurs after 1.2 million years ago when maximum transfer distances increase from $15 \mathrm{~km}$ to $100 \mathrm{~km}$. From 1.2-0.2 million years ago data on 46 transfers from six East African sites or layers show six occurrences of raw-material transfer between 15 and $100 \mathrm{~km}$ (Feblot-Augustins, 1997: inventory 10). The significance of this increase is that it demonstrates that after 1.2 million years ago, hominid groups had a new ability to exploit larger landscapes. 
Interestingly, this raw-material transfer data does not agree with Steele's calculations of home-range size based on anatomical data (1996: 249). Steele's calculations suggest a home-range size of 17-49 km for Homo erectus after its brain and body size are compared to humans and extant primates. This means that at 1.2 million years ago there was a new development that allowed raw materials to be moved over an area that is much larger than the home-range indicated by biological variables. We can rule out differences in habitat (for example from rainforest to savannah or plains to mountains) as the main explanation for the new quality because the data for the periods $2.5-1.2$ and 1.2-0.2 million years ago come from the same area of equatorial Africa. The key to understanding this new ability to transfer raw material over much greater differences is a development in the interpersonal domain that increased the potential and flexibility of communication.

This development is the ability to pool the information that individuals collect and to make decisions about group movement based on this pool of information. If information collected by members of a group is pooled then the dominant individual has more options for planning and decision-making about the movement of the group because it has information on a much larger area than that individual alone could acquire from its own experience. Mathematical modelling by Reynolds and Zeigler (1979) shows that the ability to pool information into a centralised decision maker overcomes the limitations of information gathered by individual members and allows a group to use information about a significantly larger area.

\section{Protolanguage as an adaptive response to climate change}

The cause of the change from a primate system of communication to this protolanguage may have been an adaptive response to increased aridity in Africa. Oxygen isotope evidence of global ice volume and analysis of windblown dust sediments from ocean bed cores indicate a shift in African climate variability from 41,000-year glacial cycles to 100,000-year cycles at 1.0 million years ago (deMenocal, 1995; 2004). Coincident with the change to 100,000year glacial cycles, the African sediment records suggest a marked increase in glacial amplitude (deMenocal, 1995; 2004). Further evidence of an increase in cool and dry conditions in Africa at this time comes from the fossil record of African bovidae documenting increased proportions of arid-adapted species at around 1.0 million years ago (Vrba, 1995). Homo erectus groups with the ability to pool information collected over a wide area probably had greater success surviving this change than groups without a protolanguage (Pinker and Bloom, 1990: 712). It is possible that different types of less flexible and elaborate protolanguage systems were used by Homo erectus prior to one million years 
ago. The change in climate may have functioned as a bottleneck for Homo erectus populations though which only Homo erectus groups using the most flexible and efficient protolanguage survived. Hurford (1989) and Nowak and Komarova (2001) have used evolutionary game theory to show that arbitrary bi-directional signs will be selected in preference of other communication schemes over evolutionary time. The results of Hurford's (1989) simulation indicate that the Saussurean strategy of the arbitrary bi-directional sign can become the dominant strategy of communicative behaviour when there are selective advantages for successful communication. This appears to have been the case for Homo erectus where the intensification of aridity provided conditions that selected for more complex communication systems.

It is difficult to be specific about the characteristics of this protolanguage but it must have had certain minimum attributes to allow the pooling of information. Firstly, one of the limits of primate grooming must have been overcome, namely that individuals have to be able to communicate with more than one other individual at a time. This problem is simply overcome with a signalling system based on vocal expressions or gestures (although gestures are limited by the requirement of a direct line-of-sight between participants, making it difficult to use in large groups, over long distances and in the dark). Secondly, a basic symbolic ability is required so that individuals can represent perceived phenomena to each other and pool information. The protolanguage does not imply the ability to express displacement or use of syntax so it is a less complex form of communication than the language of modern Homo sapiens.

Recent linguistic work on language evolution suggests that phonological competence may have been a crucial development at the protolanguage stage. In his model of language performance Jackendoff (2002) argues that phonology and semantics are components that are equally as important as syntax in language generation. In the context of a protolanguage, this means that syntax is not required and that an increased phonological range enables more soundmeaning pairs (or protolinguistic signs) and makes linguistic communication more efficient and flexible than a gestural system. Carstairs-McCarthy (1999) proposes a similar model where lexicon size and phonetics are significant limits to language evolution. Carstairs-McCarthy (1999) argues that the lowering of the hominid larynx from its standard mammalian high position to the low position of anatomically modern, which began during the time of Homo erectus, vastly increased vocalisation potential. This increased sound production potential drives the creation of meanings and the emergence of duality of patterning (where discrete parts of a language can be recombined in a systematic way to create new forms, such as phonemes into words and words into sentences). Carstairs-McCarthy's (1999) model is flawed by its anatomical determinism resulting in a failure to consider the evidence of Homo erectus behaviours which 
indicate what their language enabled them to do. The descent of the larynx has been observed in birds and deer and so is not uniquely human (Fitch and Reby, 2001). It may have occurred in humans for the same reasons it evolved in these other animals, to exaggerate the impression of body size conveyed by vocalisations (Fitch, 1999); it probably does not indicate the linguistic turning point suggested by Carstairs-McCarthy. Despite this flaw, I believe that Carstairs-McCarthy (1999), like Jackendoff (2002), is correct to emphasise the importance of phonology in language evolution.

Phonological competence as the key to protolanguage agrees with a Darwinian explanation of language evolution where 'every detail of grammatical competence that we wish to ascribe to selection must have conferred a reproductive advantage on its speakers' (Pinker and Bloom, 1990: 721). Lieberman (1992) notes that the human speech is characterised of high transmission rates: 15 or even up to 25 phonetic segments can be produced or recognised per second. The identification of non-speech sounds is much slower: a maximum of 7-9 items per second. Lieberman (1992) also notes the larger range of sounds that only humans among primates have the anatomy to produce. These include vowels like [i] and [u] which are more easily combined with other sounds and less susceptible to perceptual confusion than some other phonetic segments. These characteristics suggest that speed, reliability and range, which are maximised by a phonological combinatorial system, were selected for during the evolution of language. The climatic change at about one million years ago may have selected for populations using protolanguages with phonological competence over other competencies because this provides a system for pooling information efficiently and accurately with a minimum of complexity and using existing facilities such as memory and vocalisation.

The stability of the $100 \mathrm{~km}$ home-range radius for Homo erectus over one million years suggests that the protolanguage had long-term stability, while the ambiguous evidence of symbolic behaviour in the archaeological record suggests that extensive and persistent use of symbols was not common with non-modern hominids. This limits the flexibility and potential of the protolanguage, resulting in a communication system with limited expressive power. This suggests a system of interpersonal relations with a complexity greater than primates but less than modern humans.

\section{Protolanguage and the first movements into Eurasia}

At about the same time, large increase in distances of raw-material transfer are the first signs of Homo erectus colonising Europe and Asia. Archaeological sites in Europe such as Atapuerca, Ceprano, Monte Poggiolo and Orce and in West Asia such as Ubeidiya and Gesher Benut Yaaqov suggest a hominid presence 
around or just after 1.0 million years ago (Klein, 1999: 314-27). Although the evidence at these sites indicates non-intensive and short-term occupation, it may have been protolanguage that allowed Homo erectus groups to organise themselves to travel the great distances from Africa to Europe and to adapt to very different environments.

It is not until after 500,000 years ago that there are signs of intensive long-term occupation at European sites such as Boxgrove, Ambrona, Torralba, Cagny-laGarenne, Fontana Ranuccio, Isernia La Pineta, Karlich G and Miesenheim 1 (Roebroeks, 2001). This delay of 500,000 years between the first occupation and more intensive occupation is probably not related to any limitations in communicative abilities but is more likely to be a result of changes in ecological conditions. Giant hyenas (Pachycrocuta brevirostris) and sabre tooth cats (Megantereon whitei) are carnivorous predators that disappear from the faunal record at about 500,000 years ago (Arribas and Palmqvist, 1999). With the disappearance of these predators a more stable and productive hunting niche opened up for hominids (Turner, 1990; 1992). Although the human role in faunal assemblages is ambiguous at many sites dated to this period, the three 400,000-year-old throwing spears from deposits at Schöningen, Germany found in association with hundreds of horse bones, many of them with signs of butchery, provide a compelling case that these hominids occupied the niche of a hunter (Thieme, 1997). The organised hunting behaviour suggested by Schöningen may be indirect evidence of protolanguage: the provision of weapons and possible herding and butchering of horses may have required a protolanguage to coordinate the different roles of the hominid participants. That said, this evidence of hunting is not persuasive for language abilities because it may have been possible for Homo erectus to hunt using methods similar to carnivores with no language abilities.

\section{The appearance of exchange networks in the African Middle Stone Age}

Following Homo erectus, the story gets more complex because of the co-existence of populations of multiple hominid species with different cultural abilities. For example, the Neanderthals (Homo neanderthalensis) existed in Europe from about 300,000-30,000 years ago and modern forms of Homo sapiens existed in Africa from 260,000 years ago (Klein, 1999; McBrearty and Brooks, 2000). In Europe the pattern of raw-material transfers from 500,000-70,000 years ago resemble those in Africa after 1.0 million years ago, with the majority of transfers occurring within $15 \mathrm{~km}$ of the source location and some transfers up to $80 \mathrm{~km}$. The first evidence of raw-material transport beyond the 100-120 
$\mathrm{km}$ limit of Homo erectus occurs in Africa during the Middle Stone Age (MSA, c. 250-40,000 years ago). Songhor, Muguruk, Nasera Rock Shelter, GvJm-16, Mumba Rock Shelter (dated by Uranium series to $100-130,000$ years ago) and Porc Epic are excavated sites containing MSA stone artefact assemblages with artefacts made from obsidian sourced between 140 and $340 \mathrm{~km}$ away (McBrearty and Brooks, 2000: 514-15).

Ethnographic evidence suggests that transfers of materials over the Homo erectus limit of $100-120 \mathrm{~km}$ are a result of indirect procurement rather than direct collection. A global sample of 70 hunter-gatherer cultures indicates a maximum territory radius of $140 \mathrm{~km}$ (mode $15 \mathrm{~km}$, range 3-140 km, mean 32 $\mathrm{km}$, standard deviation $24 \mathrm{~km}$ ) (Kelly, 1983; 1995). This maximum figure is only approached by groups in the ecologically marginal Arctic regions, such as the Nunamiut and Baffinland Inuit and the Crow, whose mobility is aided by the use of horses (Kelly, 1995: 128-9). Raw material sourced to more than $140 \mathrm{~km}$ is therefore unlikely to have been procured during the seasonal movements of a group. Raw material moved $300 \mathrm{~km}$ during the African Middle Stone Age is double this distance and implies access to a home-range territory more than four times the maximum ethnographically observed.

In addition, ethnographic data summarised by Feblot-Augustins and Perlès (1992) indicate that although movement of around $100 \mathrm{~km}$ might be within the range of deliberate forays by mobile foraging groups, transports of raw material over more than $300 \mathrm{~km}$ result from exchange between groups. Studies of the movement of hunter-gatherer peoples and the spatial extents of their alliance networks also indicate exchange networks when distances of around 150-300 $\mathrm{km}$ are involved. Ethnographic data on the Aka pygmies of the Central African Republic show that individuals moved distances of $1-175 \mathrm{~km}$, with 96 per cent of movement being less than $100 \mathrm{~km}$ and half less than $50 \mathrm{~km}$ (Hewlett et al., 1986). It is highly unlikely that Aka individuals would transfer an object a linear distance of $300 \mathrm{~km}$ in the course of their habitual activities. Wobst's (1976) study of mating networks amongst recent hunter-gatherers indicates a maximum distance of $300 \mathrm{~km}$ between the most distant local groups involved in closed-system marriage networks. He predicts that beyond $300 \mathrm{~km}$ it is maladaptive for groups to engage in food sharing, joint ritual and exchange of sufficient intensity to maintain mate-exchange relations (Wobst, 1976: 52). In light of the ethnographic data of hunter-gatherer home-range size, movement patterns and social networks, a probable explanation for raw materials moved over $140-300 \mathrm{~km}$ is that they moved through networks of exchange involving neighbouring groups. 


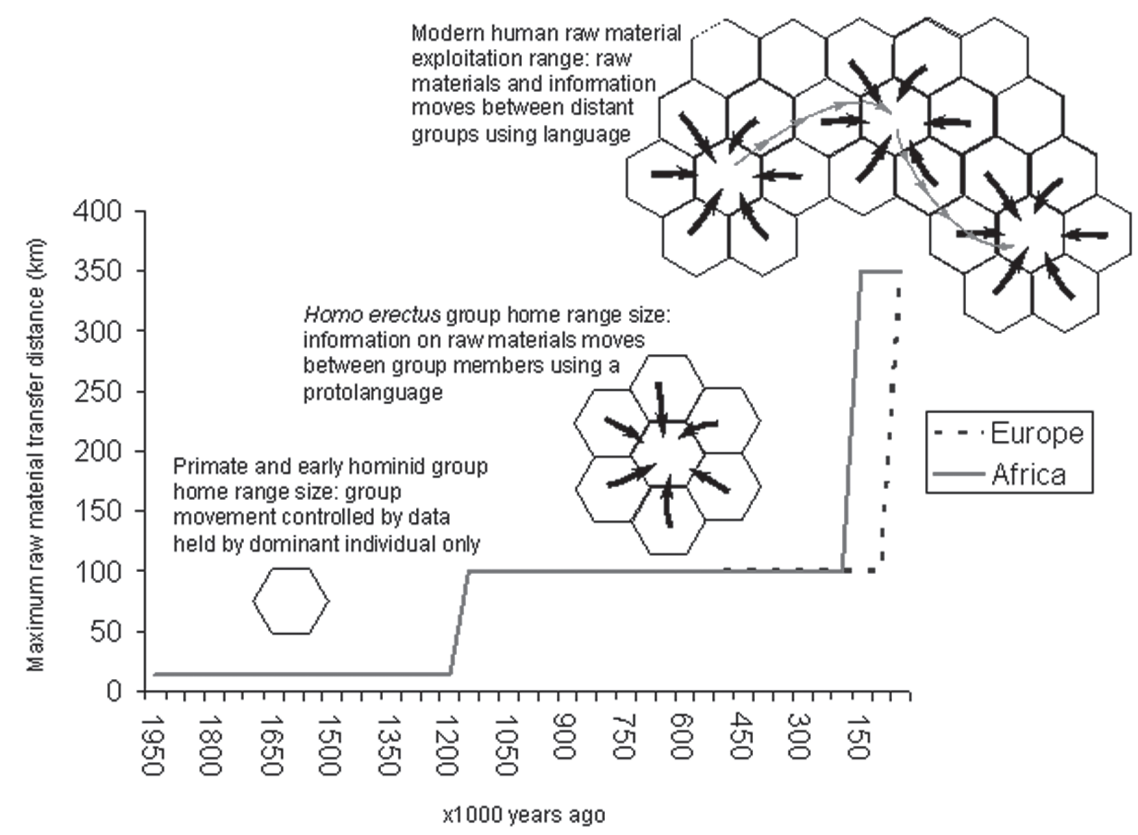

Figure 1: The three major stages of raw-material transfer and their associated language abilities. The single hexagon is a schematic representation of the social and environmental knowledge of one individual as the head decision-maker for a primate kin-group. For Homo erectus groups the decision-making individual is receiving information from, in this example, six other individuals within the same kin-group. For modern humans the decision-making individual is receiving information from within its kin-group and unrelated groups.

\section{Exchange networks as evidence for language and interpersonal communication}

Participating in exchange networks requires the specific cognitive and linguistic abilities that define modern humans. Although primates do have some interpersonal competence they do not possess the abilities that allow them to form multi-group exchange networks. Analysis by Benson et al. (2002) of Kanzi's lexicogrammatical patterns, gestures and vocalisations when he interacts with people suggests he has developed in interpersonal grammar for negotiating exchanges of goods and services. While Kanzi's example suggests that primates have the potential for skilled interpersonal negotiation, primate social interactions with strangers in the wild are typified by the uncertainty of the outcomes, which may be injury or death (Boesch and Boesch-Achermann, 
2000; Goodall, 1986; Watts and Mitani, 2001; Wilson and Wrangham, 2003). A second feature that prevents primates from operating exchange networks is their limited capacity for exchange. Primates demonstrate the ability for only indirect exchange of goods involving immediate reciprocity amongst themselves (Paquette, 1992). For hominids to operate in an exchange network, they need to avoid the uncertain outcomes primates have in meeting strangers and they need to be capable of direct exchange with delayed reciprocity.

The ability to express symbolic categorisations of social systems allows individuals to identify and interact with unrelated individuals in terms of symbolic categories rather than as unique individuals. This is a fundamental change in the interpersonal domain because it allows for relationships based on mutual rights and obligations rather than the histories of interpersonal relations that require renegotiation at each encounter (Whallon, 1989: 438). Biological kin categories may have been the archetypes for categorising unrelated or distantly related individuals in hunter-gatherer groups. For example, when two unrelated adults of similar age meet for the first time their interaction is determined by each individual's experiences of sibling or cousin relationships. Both individuals will have had some experience of sibling or cousin relationships so their relationship will be based on a set of shared concepts. Expression of displacement (beyond the here-and-now) allows individuals to negotiate delayed reciprocity as well as reference to kin relations that are not biologically-based and are specific to times and places (such as marriage relations) (Whallon, 1989: 439). Exchange networks also require syntax to express ideas in hierarchical sequences and make reference to multiple subjects and objects. This is required for the expression of multiple levels of intentionality (for example, 'I know \| that you think || I want') and in multi-party exchange negotiations. In his study of language ontogeny Halliday (2004: 34) has identified the use of language for the simultaneous representation of experience and enactment of interpersonal relationships as 'the critical step' from protolanguage to language where language-using individuals are simultaneously interpreting their own experience and enacting their interpersonal relationships. It is this ability to simultaneously interpret experience and enact relationships that greatly increases the efficiency of exchange relations.

Cross-cultural studies among human populations suggest that humans have evolved a specialised cognitive ability for the types of exchange relations in social contexts evident during the African Middle Stone Age. Sugiyamaa et al. (2002) conducted tests for cheater-detection during social exchange scenarios on Harvard undergraduates and Shiwiar hunter-horticulturalists of the Ecuadorian Amazon and found that the two groups were indistinguishably proficient at cheater-detection and uniformly poor at detecting potential violations of conditional rules in general. This suggests that cognitive adapta- 
tions to exchange networks in humans are species-typical and buffered against environmental and cultural variations. Further evidence for the specialised nature of social exchange cognition comes from a person who suffered a bicycle accident that caused bilateral damage to his medial orbitofrontal cortex and anterior temporal cortex. Stone et al. (2002) noted that the damaged areas of the cyclist's brain were key areas for social intelligence and tested him on several kinds of reasoning. The subject performed significantly worse in social contract reasoning than other types of reasoning when compared with both normal controls and with other brain-damaged subjects. These tests demonstrate that reasoning about social exchange is a specialised and separable component of human social intelligence (Stone et al., 2002). These two case studies suggest that the appearance of exchange networks and language may be related to the appearance of specialised and efficient social intelligences in anatomically modern humans and transformations of interpersonal relations that were species-wide.

\section{Further archaeological evidence for language during the African Stone Age}

The argument for symbolic ability during the African MSA is supported by evidence of symbolic behaviour at several sites (Henshilwood and Marean, 2003). Body ornaments are known from at least three African sites dating from 130,000-40,000 years ago. These include a perforated shell from Oued Djebanna (Algeria), four deliberately-drilled quartzite flakes from Debenath (Nigeria) and a bone pendant from Grotte Zouhra (Morocco) (McBrearty and Brooks, 2000: 521). A piece of ochre with abstract but systematic multiple incised hatchings at Blombos (South Africa) underlies sterile dune sands dated by Optically Stimulated Luminescence (OSL) to 73,000 years ago (Henshilwood and Sealy, 1997). Forty-one drilled shells were also recovered from Blombos in levels dated by OSL and TL (Thermoluminescence) to 75-78,000 years ago (d'Errico et al., 2005). These shells represent the best evidence so far for symbolic behaviour during the MSA because the shells have evidence of systematic, careful and controlled perforation probably for use as personal ornaments (d'Errico et al., 2005). Similarly impressive evidence of symbolic ability is the assemblage of 28 formal bone tools dated to 77,000 years ago from Blombos (Henshilwood et al., 2001). At Apollo 11 (Namibia) incised ostrich egg fragments have been dated by AAR (Amino Acid Racemisation) to $>83,000$ years ago (Miller et al., 1999). 


\section{The same evidence appears later in Europe}

The evidence of modern human behaviour similar to that found at African MSA sites does not appear in Europe until the transition from the Middle to Upper Palaeolithic around 40,000 years ago (Mellars and Stringer, 1989). Data on raw-material transfers from Europe provide evidence of modern language abilities also at around this time. The first evidence of transfers over distances greater than $140 \mathrm{~km}$ occur in central Europe during the Late Middle Palaeolithic (100-45,000 years ago) and Early Upper Palaeolithic (45-30,000 years ago). From a sample of 24 sites or layers and 82 occurrences of transfers for the Later Middle Palaeolithic in central Europe there are seven occurrences of raw-material transfers between $140 \mathrm{~km}$ and $300 \mathrm{~km}$ (Feblot-Augustins, 1997: inventory 30 ). During the Early Upper Palaeolithic in central Europe (including transitional industries such as the Szeletian and Jerzmanowician) there are 55 sites or layers and 223 occurrences of transfers, with 29 occurrences between 140 and $420 \mathrm{~km}$ (Feblot-Augustins, 1997: inventories 60, 62).

Seven occurrences of exchange is not suggestive of systematic circulation of materials through exchange networks and more convincing evidence of transfers over 140-400 km do not appear at west European sites until the Aurignacian period (35-28,000 years ago). At this time the material transferred is not stone but marine and fossil shell (Roebroeks et al., 1988). In the later Upper Palaeolithic (21-11,000 years ago) marine and fossil shells were transported over $800 \mathrm{~km}$ (Feblot-Augustins, 1997: figs. 81-4). These very longdistance transfers suggest the presence of open networks where the importance of objects is transformed from the functional to the social and ritual realms as they are circulated through the networks (Feblot-Augustins and Perlès, 1992). This resembles the case of the exotic obsidian at GvJm-16, Prospect Farm and Prolonged Drift during the African Middle Stone Age. Further developments related to language include the appearance of the first European cave paintings and portable art after 30,000 years ago, in particular the highly-stylised and widely-distributed Venus figurines (28-21,000 years ago, Klein, 1999: 545-53). The production of art and the very long-distance transfers strongly suggest the use of symbols, which is a crucial feature of language.

\section{The problem of the Neanderthals}

Raw material data for Neanderthal populations suggests they used a protolanguage similar to Homo erectus but other archaeological evidence associated with Neanderthals indicates a level of cultural and cognitive complexity greater than Homo erectus. Genetic evidence from two Neanderthal individuals suggests that Neanderthals and modern humans share Homo erectus as a common ancestor but Neanderthals have made no contribution to modern human DNA and are not an 
ancestral species (Ovchinnikov et al., 2000). The problem of the Neanderthals is: what protolanguage were they using that is more complex than the protolanguage of Homo erectus but less complex than modern human language?

Transitional stone artefact industries (those chronologically and stratigraphically located between Neanderthals and modern humans e.g. Châtelperronian) in western Europe have transfer patterns resembling Homo erectus with distances not exceeding $70 \mathrm{~km}$ (Feblot-Augustins, 1997: inventory 32). The hominids associated with the central European transitional industries are uncertain (Bolus and Conard, 2001). The raw-material transfer data from central Europe currently does not have the resolution to distinguish between material moved by the last Neanderthals or the earliest modern humans during the Middle to Upper Palaeolithic transition.

There is ambiguous evidence for some symbolic capacity amongst Neanderthal populations. Ochre fragments with signs of scraping have been found in a number of Neanderthal sites in southwest France, although there is no indication of how they were used (Mellars, 1996: 20). Over a dozen Neanderthal burials have been recorded in France and western Asia, although there is much contention about the role of burial and site-formation processes (Gargett, 1989; 1999). Most archaeologists agree that even if Neanderthals did bury their dead, the absence of convincing grave goods in the burials, and symbolic artefacts generally, indicates that ceremonial and symbolic behaviour was not widespread (Chase and Dibble, 1987). A number of sites have inscribed, perforated or worked bone pieces associated with Neanderthals although there is much ambiguity concerning the role of intentionality and symbolism in their production (Chase and Dibble, 1987; 1992; Hayden, 1993; Villa and d'Errico, 2001). Sites in western Europe, such as Arcy-Sur-Cur and St Cesaire, and in central Europe, such as Vindija and Velika Pecina, show associations of Neanderthals with Upper Palaeolithic technologies that are variously argued to result from autonomous development of local traditions, imitation, acculturation or trading with modern human populations, or to stratigraphic mixing (d'Errico et al., 2003; Hublin et al., 1996: 226; Karavanic and Smith, 1998; Lévêque et al., 1993). To sum up the archaeological evidence, Neanderthals were probably behaviourally closer to modern humans than Homo erectus, although they never demonstrated the full variety of modern behaviours observed in the African MSA and the European Upper Palaeolithic.

\section{Simulations of linguistic evolution}

A solution to the problem of Neanderthal language can be found in computer simulations of the evolution of language. These show that complex structured languages spontaneously emerge in populations of learners even though the 
population has no common signalling system and is not subject to any biological change (Kirby, 2000). Many authors have argued that syntax is a result of natural selection (Bickerton, 1998; Newmeyer, 1991; Pinker and Bloom, 1990). Recent work, however, suggests that language itself is a complex adaptive system that is 'more likely to have adapted itself to its human hosts than the other way round' (Christiansen, 1994: 125). This means that linguistic evolution must be considered a process operating in parallel with feedbacks between biological and cultural evolution. Kirby's (2000: 305) simulation takes individuals that learn observationally (rather than through explicit reinforcement), a gradual turnover of members of the population over time (ensuring true transmission of knowledge through the system), no selection of individuals (death is random to ensure that linguistic success is unrelated to adaptive success) and an initial non-linguistic population (so that any biases that emerge in the simulation are a product of the model). Communication begins because of random invention and noise events where an individual produces a randomly-constructed string of symbols (phonemes or words for example) with a randomly chosen meaning.

Although the results of Kirby's (2000) simulation are the product of an explicitly non-biological process, they provide a useful model for the emergence of syntax in human populations. The results of the simulation show three stages in the evolution of syntax (Figure 2).

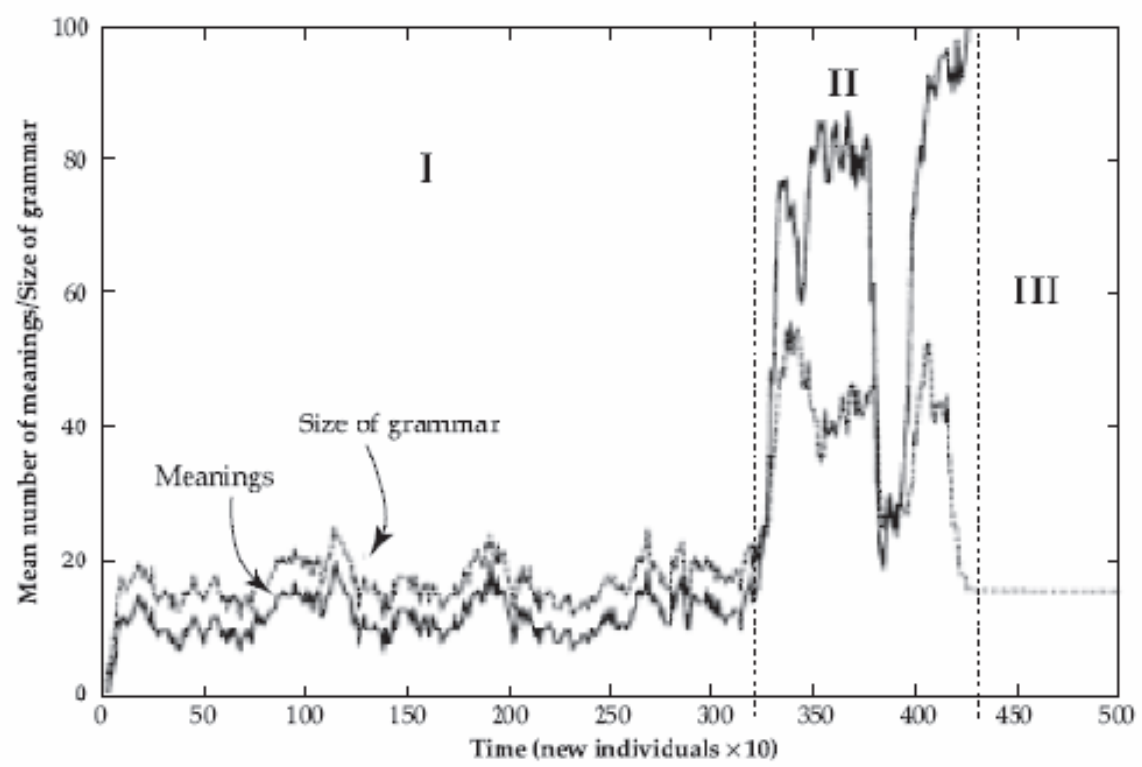

Figure 2: The results of Kirby's (2000) simulation of the non-biological evolution of syntax 
Stage One is a long and stable period where individuals are able to express a small number of the total meanings possible in the simulation using a small grammar. Grammars during this first stage are not sets of rules but vocabulary lists with meanings expressed as arbitrary unanalysed strings of symbols. Kirby (2000: 317) describes Stage One as a communication system that is 'nothing more than an inventory of calls expressing unanalysed meanings' with 'an impoverished, idiosyncratic vocabulary of one-word utterances'. The lack of syntax and the stability of the communication system in Stage One are analogous to the phonology-based protolanguage of non-modern hominids that emerged around one million years ago and lasted until about 130,000 years ago.

Stage Two is a period of unstable and unpredictable change. The size of the grammar and the number of meanings expressed increases dramatically, but fluctuates wildly. An important change from Stage One is that the number of meanings becomes greater than the number of rules in the grammar. Kirby (2000:317) describes the language of Stage Two as 'brittle... and liable to break and lose its expressive power suddenly'. He notes that the grammars at this stage are more complex than Stage One and that the details of what is going on in the language of the population at this stage are hard to figure out' (Kirby, 2000: 314). I believe that this stage is a reasonable approximation of Neanderthal linguistic abilities, with their behavioural capacity somewhere between Homo erectus and modern humans, but their raw-material transfers firmly in the range of earlier non-modern hominids. The type of language emerging at Stage Two of the simulation may have permitted Neanderthals to have more complex social organisation and behaviours within local kin groups, but lacked the stability and flexibility to maintain multi-group networks over large areas and long periods. This lack of stability and flexibility may explain why Neanderthal raw-material transfer distances are similar to those of earlier non-modern hominids and why Neanderthals did not develop cultural behaviours that became persistent and widespread.

Following an abrupt transition, the third stage of the simulation appears with a sudden increase in the number of meanings that can be produced to the maximum value allowed by the simulation and a drop in the size of the grammars (Kirby, 2000: 314). There is now a regular correspondence between meanings and expressions and the individuals' grammars are compositional and have syntactic categories for nouns and verbs. This stage constitutes a simple system with long-term stability and great expressive power. The third stage is an ideal analogue for the emergence of modern language, with syntax and massive expressive power controlled by a relatively simple productive system consisting of a few general rules. This point represents the break from the simple addition of signals in a linear protolanguage to a system of combina- 
tion and recursiveness which is required to increase expressive power and limit error rates (Nowak et al., 1999).

Although it seems likely that Neanderthals were operating with a Stage Two language, whether or not they made it to Stage Three may never be known. Non-biological linguistic evolution and biological and cultural evolution influence each other in ways that are difficult to predict (Deacon, 1997; Kirby and Hurford, 1997; 2001). Mathematical models of language evolution show that once language abilities appear in a population and certain demographic and information thresholds are reached, evolutionary processes select for language in favour of other communication systems (Nowak and Krakauer, 1999; Nowak et al., 2001). Biological and cultural differences between Neanderthals and modern humans probably produced different patterns of linguistic evolution that resulted in modern humans arriving in Europe with language and replacing the less loquacious Neanderthals.

While Kirby's simulations help us to understand the abilities of the Neanderthals, further simulations by Tonkes and Wiles (2002) reveal interesting details relating to the length of the learning period and the population size. Their simulations show that populations converge on languages regardless of their size, but that the time taken to converge is greater in larger populations. In larger populations, the communicative error rate is higher and the possibility of two or more different languages emerging is higher, taking greater time for one language to dominate and the error rate to stabilise at a tolerable level. This suggests that a relatively small population size was optimal for the emergence of language and exchange networks.

\section{Biological evidence for the timing of language emergence}

Genetic evidence, such as segregating Alu insertions, mitochondrial mismatch distributions, $\mathrm{X}$ and $\mathrm{Y}$ chromosome microsatellite loci and protein polymorphism, indicate a suite of coalescent events between 180,000 and 120,000 years ago (Goldstein et al., 1995; Hammer et al., 1997; Harding et al., 1997; Harpending et al., 1993; Harris and Hey, 1999; Nei and Roychoudhury, 1974; Stoneking et al., 1997). These coalescences are interpreted by Harpending et al. (1998) and Reich and Goldstein (1998) as the result of a population bottleneck roughly coincident with a glacial phase peaking around 130,000 years ago (Lahr and Foley, 1998: 163-4). In light of the simulations of Tonkes and Wiles (2002) the population contraction at 130,000 years ago is an optimum condition for the emergence of language, allowing its spread to be rapid and minimising the possibility of maladaptive and prolonged communicative errors and multiple mutually unintelligible languages. 
Interestingly, this is very close to the time that FOXP2 gene became fixed in humans (Enard et al., 2002). Mutations in this gene, which is found in humans, mice and primates, have been shown to cause a wide variety of speech and language disabilities in humans (Lai et al., 2001). Although it is incorrect to call FOXP2 a 'language gene' it is likely that this gene controls the expression of other genes that are more directly related to proficiency in spoken language (Marcus and Fisher, 2003). Various authors have suggested a specific evolutionary process - the Baldwin effect - to explain how a complex behaviour such as language can be encoded in the human genome (Deacon, 1997; Pinker and Bloom, 1990). The Baldwin effect explains how learnt behaviours, such as environmentally induced responses, can change the selection pressures acting on an organism so that these behaviours become innate. Deacon (1997) proposes that during the process of biologically-independent linguistic evolution, individuals who possessed genetic mutations that improved the language learning process would have greater reproductive success than other individuals without the mutation. Improved language abilities confer selective advantages because the error rates and ambiguities of communication are reduced, making negotiation and exchange of social and natural resources more efficient, reliable and predictable. These mutations might result in enhancements in cognitive abilities that support language such as attention, imitation or automatic reflection (Deacon, 1997). Support for this proposal comes from the artificial life models of Munroe and Cangelosi (2002) that simulate the evolution of compositional languages. Their model shows that when the structure of language varies during cultural transmission, Baldwinian processes cause the assimilation of a predisposition to learn (such as general underlying cognitive capabilities) rather than the assimilation of specific structural features of language (Munroe and Cangelosi, 2002). These Baldwinian processes may also explain the development of the specialised cognitive faculty for exchange relations discussed above; the close relationship between language and exchange behaviours suggests that the relevant cognitive faculties may have appeared at about the same time.

Simulations by Tonkes and Wiles (2002) and modelling by Nowak and Komarova (2001) also show that longer learning periods vastly reduce the communication error rate in a population and increase the probability of a successful language emerging. The length of learning period of the hominid can be identified archaeologically by the rate of enamel formation in teeth. A fast rate of enamel formation suggests a short, rapid learning period and a low rate suggests a longer, slower learning period. Dean et al. (2001) analysed daily incremental markings in enamel to calculate rates of enamel formation in 13 fossil hominid specimens dating between 4.0 million and 120,000 years ago. They found that the slow trajectory of enamel growth during prolonged maturation that is typical of modern humans appeared relatively late in homi- 
nid evolution, at around 120,000 years ago (Dean et al., 2001). This evolution of a longer maturation and learning period may have been the final anatomical precondition that allowed for the emergence of language following the lowered larynx, an appropriately shaped hyoid bone, muscular control of the tongue and chest and an adequate angle of basicranial flexion.

\section{Conclusion}

This paper has outlined a model of language development using distances of raw-material transfer and other evidence as proxy variables for changes in interpersonal communication abilities. The sequence of language evolution presented here is similar to the sequence of language ontogenesis suggested by Halliday (1994: 70) where the exchange of goods-and-services, with language as the means, comes much earlier than the exchange of information'. Distances of raw-material transfer by Pleistocene hominids show three important stages that relate to language ability. The first stage begins at about 1.9 million years ago with a maximum raw-material transfer distance of $13 \mathrm{~km}$ and shows early hominids to have had a capacity for planning greater than chimpanzees. The second stage occurs at about 1.0 million years ago when the maximum transfer distance increases to $100 \mathrm{~km}$, suggesting the presence of a protolanguage that facilitates pooling of information. This enabled African non-modern hominid groups to exploit much larger territories than before. The intensified aridity of the African climate 1.0 million years ago selected for a protolanguage based on phonological competence that allowed basic symbolic reference.

The third stage is marked by maximum transfer distances of $>300 \mathrm{~km}$, first appearing in Africa 130,000 years ago and after 100,000 years ago in Europe. This third stage represents the emergence of exchange networks that require a communication system allowing expression of displacement and symbolic categorisation of social systems, which are the attributes of human language. At around 130,000 years ago biological evidence suggests small population sizes, the appearance of a gene that is related to language ability and the appearance of a delayed maturation in human life history. Computer simulations indicate that these features provide optimum conditions for the evolution of language. A computer simulation produced by Kirby (2000) shows that non-biological evolution can transform a protolanguage into a language. I propose that the intermediate stage of languages (Kirby's Stage Two) that are highly unstable and highly variable in their complexity and expressive power may explain the paradox of the Neanderthals who may have been capable of some near-modern behaviours but did not use exchange networks. A significant detail of Kirby's simulations is the importance of non-biological linguistic evolution which must be considered along with biological and cultural evolution. I have suggested that 
Baldwinian processes stimulated by linguistic evolution were responsible for the biological assimilation of language-related abilities and exchange reasoning. Explanations of language evolution are often accused of being unverifiable just-so stories, but the core argument of this paper is capable of testing through the collection of additional data on raw-material transfers in Africa, Europe and Asia. If the timing of the crucial thresholds of $13 \mathrm{~km}, 100 \mathrm{~km}$ and $300 \mathrm{~km}$ are shown to be unreliable and fail to be confirmed in future research (which should consider data from China, central Asia and southeast Asia [Keates, 2004]) then the narrative proposed here can be rearranged or rejected altogether.

\section{Acknowledgments}

Thanks to Jane Balme for reading an earlier version of this article. Thanks also to Michael Arbib, Iain Davidson, Terrance Deacon, Huck Turner, Janet Wiles, Simon Kirby, Jim Hurford and John Henderson for their comments on previous presentations of this article. Thanks to Geoff Williams for suggesting that I submit this paper and providing useful resources and feedback.

\section{Notes}

1 The species with the longest duration between early Homo and modern humans, erectus, is used here as a generic term to include H. ergaster, heidelbergensis and similar hominids.

\section{References}

Arribas, A. and Palmqvist, P. (1999) On the ecological connection between sabre-tooths and hominids: faunal dispersal events in the lower pleistocene and a review of the evidence for the first human arrival in Europe. Journal of Archaeological Science 26: 571-85.

Baldwin, P. J., McGrew, W. C. and Tutin, C. E. (1982) Wide ranging chimpanzees at Mt Assirik, Senegal. International Journal of Primatology 3: 367-85.

Benson, J., Fries, P., Greaves, W., Iwamoto, K., Savage-Rumbaugh, S. and Taglialatela, J. (2002) Confrontation and support in bonobo-human discourse. Functions of Language 9(1): 1-38.

Bickerton, D. (1998) Catastrophic evolution: the case for a single step between protolanguage to full human language. In J. R. Hurford, M. Studdert-Kennedy and C. Knight (eds) Approaches to the Evolution of Language: social and cognitive bases. Cambridge: Cambridge University Press.

Bickerton, D. (1981) Roots of Language. Ann Arbor, MI: Karoma.

Boesch, C. and Boesch, H. (1984) Mental map in wild chimpanzees: an analysis of hammer transports for nut cracking. Primates 25: 160-70.

Boesch C. and Boesch-Achermann, H. (2000) The Chimpanzees of the Taï Forest: behavioral ecology and evolution. Oxford: Oxford University Press. 
Bolus, M. and Conard, N. J. (2001) The Late Middle Palaeolithic and Earliest Upper Palaeolithic in Central Europe and their relevance for the out of Africa hypothesis. Quaternary International 75: 29-40.

Carstairs-McCarthy, A. (1999) The Origins of Complex Language: an inquiry into the evolutionary beginnings of sentences, syllables and truth. Oxford: Oxford University Press.

Chase, P. G. and Dibble, H. L. (1987) Middle Palaeolithic symbolism: a review of current evidence and interpretations. Journal of Anthropological Archaeology 6: 263-96.

Chase P. G. and Dibble, H. L. (1992) Scientific archaeology and the origins of symbolism: a reply to Bednarik. Cambridge Archaeological Journal 2(1): 43-51.

Christiansen, M. H. (1994) Infinite languages, finite minds: connectionism, learning and linguistic structures. Unpublished PhD thesis, University of Edinburgh.

Davidson, I. (2002) The 'finished artefact fallacy': Acheulean handaxes and language origins. In A. Wray (ed.) The Transition to Language. Oxford: Oxford University Press.

Deacon, T. W. (1997) The Symbolic Species: the co-evolution of language and the brain. New York: W. W. Norton.

Dean, C., Leakey, M. G., Reid, D., Schrenk, F., Schwartz, G. T., Stringer, C. and Walker, A. (2001) Growth processes in teeth distinguish modern humans from Homo erectus and earlier hominins. Nature 414: 628-31.

deMenocal, P. B. (1995) Plio-Pleistocene African climate. Science 270: 53-9.

deMenocal, P. B. (2004) African climate change and faunal evolution during the PliocenePleistocene. Earth and Planetary Science Letters 220: 3-24.

d'Errico, F., Henshilwood, C., Lawson, G., Vanhaeren, M., Tillier, A-M., Soressi, M., Bresson, F., Maureille, B., Nowell, A., Lakarra, J., Backwell, L. and Julien, M. (2003) Archaeological evidence for the emergence of language, symbolism and music - an alternative multidisciplinary perspective. Journal of World Prehistory 17(1): 1-70.

d'Errico, F., Henshilwood, C., Vanhaerend, M. and Niekerk, K. (2005) Nassarius kraussianus shell beads from Blombos Cave: evidence for symbolic behaviour in the Middle Stone Age. Journal of Human Evolution 48: 3-24.

Dunbar, R. I. M. (1992) Neocortex size as a constraint on group size in primates. Journal of Human Evolution 20: 469-93.

Dunbar, R. I. M. (1993) Coevolution of neocortical size, group size and language in humans. Behavioral and Brain Sciences 16: 681-735.

Dunbar, R. I. M. (1996) Grooming, Gossip and the Evolution of Language. London: Faber and Faber.

Dunbar, R. I. M. (2003) The social brain: mind, language and society in evolutionary perspective. Annual Review of Anthropology 32: 163-81.

Enard, W., Przeworski, M., Fisher, S. E., Lai, C. S., Wiebe, V., Kitano, T., Monaco, A. P. and Paabo, S. (2002) Molecular evolution of FOxP2, a gene involved in speech and language. Nature 418: 869-72.

Feblot-Augustins, J. (1997) La Circulation des Matières Premières au Paléolithique. (Etudes et Recherches Archaeologiques de l'Universite de Liège 75.) Liège: University de Liège. 
Feblot-Augustins, J. and Perlès, C. (1992) Perspectives Ethnoarchéologiques sur les Échanges à Longue Distance. Ethnoarchéologie: justification, problémes, limites, XIIe recontres internationales d'archéologie et d'histoire d'Antibes 195-209. Juan-les-Pins: APDCA.

Fitch, W. T. (1999) Acoustic exaggeration of size in birds by tracheal elongation: comparative and theoretical analyses. Journal of Zoology (London) 248: 31-49.

Fitch, W. T. and Reby, D. (2001) The descended larynx is not uniquely human. Proceedings of the Royal Society of London B 268: 1669-75.

Garber, P. A. (2000) Evidence for the use of spatial, temporal and social information by primate foragers. In S. Boinski and P. A. Garber (eds) On the Move: how and why animals travel in groups. Chicago: University of Chicago Press.

Gargett, R. H. (1989) Grave shortcomings: the evidence for neanderthal burial. Current Anthropology 30: 157-90.

Gargett, R. H. (1999) Middle Palaeolithic burial is not a dead issue: the view from Qafzeh, Saint-Césaire, Kebara, Amud and Dederiyeh. Journal of Human Evolution 37: 27-90.

Goldstein, D. B., Linares, A. R., Cavalli-Sforza, L. L. and Feldman, M. W. (1995) Genetic absolute dating based on microsatellites and the origin of modern humans. Proceedings of the National Academy of Sciences of the USA 92: 6723-7.

Goodall, J. (1986) The Chimpanzees of Gombe: patterns of behaviour. Cambridge, MA: Harvard University Press.

Halliday, M. A. K. (1975) Learning How to Mean: explorations in the development of language. London: Arnold.

Halliday, M. A. K. (1993) Towards a language based theory of learning. Linguistics and Education 5: 93-116.

Halliday, M. A. K. (1994) An Introduction to Functional Grammar. Second edition. London: Edward Arnold.

Halliday, M. A. K. (2004) On grammar as the driving force from primary to higher-order consciousness. In G. Williams and A. Lukin (eds) The Development of Language: functional perspectives on species and individuals. London: Continuum.

Hammer, M. F., Spurdle, A. B., Karafet, T., Bonner, M. R., Wood, E. T., Novelletto, A., Malaspina, P., Mitchell, R. J., Horai, S., Jenkins, T. and Zegura, S. L. (1997) The geographic distribution of human Y chromosome variation. Genetics 145: 787-805.

Harding, R. M., Fullerton, S. M., Griffiths, R. C., Bond, J., Cox, M. J., Schneider, J. A., Moulin, D. S. and Clegg, J. B. (1997) Archaic African and Asian lineages in the genetic ancestry of modern humans. American Journal of Human Genetics 60: 772-89.

Harpending, H. C., Sherry, S. T., Rogers, A. R. and Stoneking, M. (1993) The genetic structure of ancient human populations. Current Anthropology 34: 483-96.

Harpending, H. C., Batzer, M. A., Gurven, M., Jorde, L. B., Rogers, A. R. and Sherry, S. T. (1998) Genetic traces of ancient demography. Proceedings of the National Academy of Sciences of the USA 95: 1961-7.

Harris, E. and Hey, J. (1999) X Chromosome evidence for ancient human histories. Proceedings of the National Academy of Sciences of the USA 96: 3320-24. 
Hayden, B. (1993) The cultural capacities of Neanderthals: a review and re-evaluation. Journal of Human Evolution 24: 113-46.

Henshilwood, C. S., d'Errico, F., Marean, C., Milo, R. and Yates, R. (2001) An early bone tool industry from the Middle Stone Age at Blombos Cave, South Africa: implications for the origins of modern human behaviour, symbolism and language. Journal of Human Evolution 41: 631-78.

Henshilwood, C. S., d’Errico, F., Yates, R., Jacobs, Z., Tribolo, C., Duller, G. A. T., Mercier, N., Sealy, J. C., Valladas, H., Watts, I. and Wintle, A. G. (2002) Emergence of modern human behavior: Middle Stone Age engravings from South Africa. Science 295: $127-1280$.

Henshilwood, C. S. and Marean, C. W. (2003) The origin of modern human behaviour: critique of the models and their test implications. Current Anthropology 44(5): 627-51.

Henshilwood, C. S. and Sealy, J. C. (1997) Bone artefacts from the Middle Stone Age at Blombos Cave, Southern Cape, South Africa. Current Anthropology 38: 890-95.

Hewlett, B. S., von de Koppel, J. and Cavalli-Sforza, L. L. (1986) Exploration and mating range of Aka Pygmies of the Central African Republic. In L. L. Cavalli-Sforza (ed.) African Pygmies. New York, NY: Academic Press.

Holloway, R. L. (1983) Human Paleonotological evidence relevant to language behavior. Human Neurobiology 2: 105-14.

Hublin, J. J., Spoor, F., Braun, M., Zonneveld, F. and Condemi, S. (1996) A Late Neanderthal associated with Upper Paleolithic artifacts. Nature 381: 224-6.

Hurford, J. (1989) Biological evolution of the Saussurean sign as a component of the language acquisition device. Lingua 77: 187-222.

Jackendoff, R. (2002) Foundations of Language: brain, meaning, grammar, evolution. Oxford: Oxford University Press.

Joffe, T. H. (1997) Social pressures have selected for an extended juvenile period in primates. Journal of Human Evolution 32: 593-605.

Kaminski, J., Call, J. and Fischer, J. (2004) Word learning in a domestic dog: evidence for 'fast mapping. Science 304: 1682-3.

Karavanic, I. and Smith, F. (1998) The Middle/Upper Paleolithic interface and the relationship of Neanderthals and early modern humans in the Hrvatsko Zagorje, Croatia. Journal of Human Evolution 34: 223-48.

Keates, S. G. (2004) Home range size in Middle Pleistocene China and human dispersal patterns in Eastern and Central Asia. Asian Perspectives 43: 227-47.

Kelly, R. L. (1983) Hunter-gatherer mobility strategies. Journal of Anthropological Research 39: 277-306.

Kelly, R. L. (1995) The Foraging Spectrum: diversity in hunter-gatherer lifeways. Washington, DC: Smithsonian Institution Press.

Kirby, S. (2000) Syntax without natural selection: how compositionality emerges from vocabulary in a population of learners. In C. Knight, M. Stoddert-Kennedy and J. R. Hurford (eds) The Evolutionary Emergence of Language: social function and the origins of linguistic form. Cambridge: Cambridge University Press. 
Kirby, S. and Hurford, J. (1997) Learning, culture and evolution in the origin of linguistic constraints. In P. Husbands and S. Rasmussen (eds) Artificial Life II. Reading, MA: Addison-Wesley.

Kirby, S. and Hurford, J. (2001) The emergence of linguistic structure: an overview of the iterated learning model. In A. Cangelosi and D. Parisi (eds) Simulating the Evolution of Language. London: Springer Verlag.

Klein, R. G. (1999) The Human Career. Chicago: Chicago University Press.

Lahr, M. M. and Foley, R. A. (1998) Towards a theory of modern human origins: geography, demography and diversity on recent human evolution. Yearbook of Physical Anthropology 41: 137-76.

Lai, C. S. L., Fisher, S. E., Hurst, J. A., Vargha-Khadem, F. and Monaco, A. P. (2001) A forkhead-domain gene is mutated in a severe speech and language disorder. Nature 413: 519-23.

Lévêque, F., Bocker, A. M. and Guilbaud, M. (1993) Context of a late Neanderthal: implications of multidisciplinary research for the transition to Upper Palaeolithic adaptations at Sainte-Cesaire, Charente-Maritime, France. Madison: Prehistory Press.

Lieberman, P. (1992) On the evolution of human language. In J. A. Hawkins and M. GellMann (eds) The Evolution of Human Language. New York: Addison-Wesley.

Lieberman, P. (1994) Biologically bound behavior, free-will and human evolution. In J. I. Casti and A. Karlqvist (ed.) Conflict and Cooperation in General Evolutionary Processes. New York: Wiley.

Marcus, G. F. and Fisher, S. E. (2003) FOxP2 in focus: what can genes tell us about speech and language? Trends in Cognitive Sciences 7(6): 256-62.

Marwick, B. (2003) Pleistocene exchange networks as evidence for the evolution of language. Cambridge Archaeological Journal 13(1): 67-81.

McBrearty, S. and Brooks, A. S. (2000) The revolution that wasn't: a new interpretation of the origin of modern human behaviour. Journal of Human Evolution 39: 453-563.

McGrew, W. C., Baldwin, P. J. and Tutin, C. E. G. (1981) Chimpanzees in a hot, dry and open habitat: Mt Assirik, Senegal, West Africa. Journal of Human Evolution 10: 227-44.

Mellars, P. A. (1996) Symbolism, language and the Neanderthal mind. In P. A. Mellars and K. R. Gibson (eds) Modelling the Early Human Mind. (McDonald Institute Monograph.) Cambridge: McDonald Institute for Archaeological Research.

Mellars, P. A. and Stringer, C. (1989) The Human Revolution: behavioural and biological perspectives on the origins of modern humans. Princeton: Princeton University Press.

Miller, G. H., Beaumont, P. B., Brooks, A. S., Deacon, H. J., Hare, P. E. and Jull, A. J. T. (1999) Earliest modern humans in South Africa dated by isoleucine epimerization in ostrich eggshell. Quaternary Science Review 18: 1537-48.

Mithen, S. (1996) The Prehistory of the Mind: the cognitive origins of art, religion and science. London: Thames and Hudson.

Munroe, S. and Cangelosi, A. (2002) Learning and the evolution of language: the role of cultural variation and learning cost in the Baldwin effect. Artificial Life 8(4): 311-39.

Nei, M. and Roychoudhury, A. K. (1974) Genetic variation within and between the three major races of man: Caucasoids, Negroids and Mongoloids. American Journal of Human Genetics 26: 421-43. 
Newmeyer, F. (1991) Functional explanation in linguistics and the origin of language. Language and Communication 11: 1-28.

Noble, W. and Davidson, I. (1996) Human Evolution, Language and Mind: a psychological and archaeological inquiry. Cambridge: Cambridge University Press.

Nowak, M. A. and Komarova, N. (2001) Towards an evolutionary theory of language. Trends in Cognitive Sciences 5(7): 288-95.

Nowak, M. A., Komarova, N. and Niyogi, P. (2001) Evolution of universal grammar. Science 291: 114-18.

Nowak, M. A. and Krakauer, D. C. (1999) The evolution of language. Proceedings of the National Academy of Sciences of the USA 96: 8028-33.

Nowak, M. A., Krakauer, D. C. and Dress, A. (1999) An error limit for the evolution of language. Proceedings of The Royal Society of London. Series B, Biological Sciences 2131-6.

Ovchinnikov, I. V., Götherströms, A., Romanova, P. R., Kharitonov, V. M., Lidens, K. and Goodwin, W. (2000) Molecular analysis of Neanderthal DNA from the Northern Caucasus. Nature 404: 490-93.

Painter, C. (2004) The 'interpersonal first' principle in child language development. In G. Williams and A. Lukin (eds) The Development of Language: functional perspectives on species and individuals. New York, NY: Continuum.

Paquette, D. (1992) Object exchange between captive chimpanzees: a case report. Human Evolution 7: 11-15.

Pinker, S. and Bloom, P. (1990) Natural language and natural selection. Behavioral and Brain Sciences 13: 707-86.

Reed, K. E. (1997) Early hominid evolution and ecological change through the African Plio-Pleistocene. Journal of Human Evolution 32: 289-322.

Reich, D. E. and Goldstein, D. B. (1998) Genetic evidence for a Palaeolithic human population expansion in Africa. Proceedings of the National Academy of Sciences of the USA 95: 8119-23.

Reynolds, R. G. and Zeigler, B. P. (1979) A formal mathematical model for the operation of consensus based hunting-gathering bands. In C. Renfrew and K. L. Cook (eds) Transformations: mathematical approaches to culture change. New York: Academic Press.

Roebroeks, W. (2001) Hominid behaviour and the earliest occupation of Europe: an exploration. Journal of Human Evolution 41: 437-61.

Roebroeks, W., Kolen, J. and Rensik, E. (1988) Planning depth, anticipation and the organization of Middle Palaeolithic technology: the 'archaic natives' meet Eve's descendants. Helenium 28: 17-34.

Semaw, S. (2000) The world's oldest stone artefacts from Gona, Ethiopia: their implications for understanding stone technology and patterns of human evolution between 2.6-1.5 million years ago. Journal of Archaeological Science 27: 1197-214.

Smith, B. H. and Tompkins, R. L. (1995) Toward a life history of the hominidae. Annual Review of Anthropology 24: 257-79. 
Steele, J. (1996) On predicting hominid group sizes. In J. Steele and S. Shennan The Archaeology of Human Ancestry: power, sex and tradition. London: Routledge.

Stone, V. E., Cosmides, L., Tooby, J., Kroll, N. and Knight, R. T. (2002) Selective impairment of reasoning about social exchange in a patient with bilateral limbic system damage. Proceedings of the National Academy of Sciences of the USA 99(17): 11531-6.

Stoneking M., Fontius, J. J., Clifford, S. L., Soodyall, H., Arcot, S. S., Saha, N., Jenkins, T., Tahir, M. A., Deininger, P. L. and Batzer, M. A. (1997) Alu insertion polymorphisms and human evolution: evidence for a larger population size in Africa. Genome Research 7: 1061-71.

Sugiyamaa, L. S., Tooby, J. and Cosmides, L. (2002) Cross-cultural evidence of cognitive adaptations for social exchange among the Shiwiar of Ecuadorian Amazonia. Proceedings of the National Academy of Sciences of the USA 99(17): 11537-42.

Taglialatela, J. P., Savage-Rumbaugh, S., Rumbaugh, D. M., Benson, J. and Greaves, W. (2004) Language, apes and meaning-making. In G. Williams and A. Lukin (eds) The Development of Language: functional perspectives on species and individuals. New York: Continuum.

Thieme, H. (1997) Lower Palaeolithic hunting spears from Germany. Nature 385: 807-10.

Tonkes, B. and J. Wiles (2002) Methodological issues in stimulating the emergence of language. In A. Wray (ed.) The Transition to Language. Oxford: Oxford University Press.

Turner, A. (1990) The evolution of the guild of larger terrestrial carnivores in the PlioPleistocene of Africa. Geobios 23: 349-68.

Turner, A. (1992) Large carnivores and earliest European hominids: changing determinants of resource availability during the Lower and Middle Pleistocene. Journal of Human Evolution 22: 109-26.

Villa, P. and d'Errico, F. (2001) Bone and ivory points in the Lower and Middle Palaeolithic of Europe. Journal of Human Evolution 41: 69-112.

Vrba, E. S. (1995) The fossil record of African antelopes (Mammalia, Bovidae) in relation to human evolution and paleoclimate. In E. S. Vrba, H. H. Denton, T. C. Partridge and L. H. Burckle (eds) Paleoclimate and Evolution with Emphasis on Human Origins. New Haven: Yale University Press.

Watts, D. P. and Mitani, J. C. (2001) Boundary patrols and intergroup encounters in wild chimpanzees. Behaviour 138: 299-327.

Whallon, R. (1989) Elements of culture change in the Later Palaeolithic. In P. A. Mellars and C. Stringer (eds) The Human Revolution: behavioural and biological perspectives on the origins of modern humans. Princeton: Princeton University Press.

Wilson, M. L. and Wrangham, R. W. (2003) Intergroup relations in chimpanzees. Annual Review of Anthropology 32: 363-92.

Wobst, H. M. (1976) Locational relationships in Palaeolithic Society. Journal of Human Evolution 5: 49-58.

Wrangham, R. W. (1987) The significance of African apes for reconstructing human social evolution. In W. G. Kinzey (ed.) The Evolution of Human Behaviour: primate models. Albany: State University of New York Press. 